\title{
DETERMINANTS OF NON-PERFORMING LOAN IN COMMERCIAL BANKS: EVIDENCE IN VIETNAM
}

\author{
NGUYEN KIM QUOC TRUNG \\ Foreign Trade University, Ho Chi Minh City Campus
}

\begin{abstract}
The main purpose of the article is to model the main factors affecting non-performing loan incurred in the process of lending to clients in Vietnam's commercial joint stock banks during the period of 2009 - 2017. The theories and empirical research studies for the macro and micro factors affecting nonperforming loan are mentioned in the research paper. Using the qualitative research method and the quantitative research, the article analyzes the practical credit situation of the whole banking system in Vietnam and non-performing loan ratios of selected banks. In addition, the Generalized Method of Moments (GMM) is used in the study to model the major factors impact on non-performing loan. The final results showed that the paper has constructed two models with the result as followed, the first model has six statistically significant variables while the second one has only five variables statistically significant.
\end{abstract}

Keywords. Non-performing loan, GMM, net income to equity, net income to assets, leverage ratio, growth of gross domestic product.

\section{INTRODUCTION}

Lending to customers takes a large proposition in the investment portfolio and also accounts for the most profit for banks, but it is one of the causes of instability and creates the greatest risk to the financial system. Although there has been a shift in the profit structure of the bank, accordingly, the income from credit activities tends to decrease and the service revenue tends to increase but the income from credit activities still accounts for over $50 \%$ to $70 \%$ of banks' income. Non-performing loan (NPL) is one of the factors affecting the financial performance of the banks. There are many studies on NPL in some countries around the world and focusing on the causes of non-performing loans in banks. Based on those previous research studies, the main objective of the article is to build a model of the main factors affecting NPL in Vietnam's joint stock commercial banks in the context of globalization. To achieve this goal, the study aims to answer the question: "What are the main factors have affected NPL?"

The contribution of the article will be presented at two different points between the results of this study and the results of previous research studies. Firstly, the significant variable is leverage ratio (one of the indicators mentioned in Basel III). On contrary to previous research studies, the correlation in the relationship between NPL and leverage ratio is positive. This difference will be explained by corporate governance theory. Secondly, the result of this study contradicts some previous studies, the bank's performance (profitability) includes return on equity (ROE) and return on total assets (ROA) have the positive impact on NPL because most studies used "bad management theory" to explain the reason. When banks operate efficiently that means they can control and manage NPL at low level. However, according to this paper's results, the correlation between ROE (ROA) and NPL is negative. The portfolio theory, profits and risks (high risk, high return) are used to explain the difference between the results of this article and some previous empirical studies. These two points are also new contributions of the article.

\section{LITERATURE REVIEW AND EMPIRICAL RESEARCH STUDIES}

\subsection{Literature review}

Non- performing loans (NPLs) are defined as defaulted loans which banks are unable to profit from ( [59]). According to the International Monetary Fund ( [34]) a non- performing loan is any loan in which interest and principal payments are more than 90 days overdue ([34]). They often refer to loans for a relatively long time without generating income. That is the principal and / or interest on these loans that have been left unpaid for at least 90 days. Typically, a large number or percentage of bad loans are often associated with bank failures and financial crises in both developing and developed countries ([34]). 


\section{EVIDENCE IN VIETNAM}

Non-performing loan is derived from the inside and outside factors of the bank. However, in this research, it is limited by internal factors that affect the loans. So, the important aspect is how the board of executives and managers need to have a way of effectively managing the loan portfolio in the asset portfolios of the bank. In this study, non-performing loan is understood as a loan overdue for several months or a loan that fails to pay interest and principal. That may be the result of economic difficulties and non-performing loan is an indicator shows the borrower's ability be unable to repay the loan. Nonperforming loan is a burden for both lenders and borrowers. According to the State Bank of Vietnam, non-performing loan or bad debt is classified into group 3 (substandard debt), group 4 (doubtful) and group 5 (non-performing loan or non-performing loan). It is in the study will be considered as nonpayment of principal and interest due in the process of lending to customers.

Based on the view of management accounting, the quality of banks' assets and operational efficiency are positively correlated. If the quality of the bank's assets is not good enough (for example, the loan amount becomes the amount to be recovered) that means non-performing loans of banks have increased, as well as they have to spend more resources for the recovery of those loans and unpaid debts. The increase in non-performing loans in the banking sector may occur due to external factors, such as the unfavorable situation in economic activity ( [13]). They also argue that the efficiency of banks can affect inefficient loans (non-performing loans) in the banking system. Bad management hypothesis was developed to explain this relationship. [13] argue that the ineffectiveness of banks will lead to the decrease of performances and the quality of their assets, and hence the loan process will be influenced. From poor management leading to loosely managed in lending processes and procedures so the banks may not thoroughly evaluate their credit records due to poor appraisal skills. In addition, asymmetric information issues between lenders and borrowers continue to complicate matters. As a result, the lower credit ratings for approved loans will lead to the higher probability of non-performing loans.

In fact, there are many evidences that the financial crises incurred from high non-performing loans. The global financial crisis in 2007 - 2008, for instance, was attributed to the rapid default of sub-prime mortgages ([34]). This explain why much research studies emphasized on non-performing loans when examining financial vulnerabilities of the financial system of the national economy. Because of serious consequence of non-performing loans, commercial banks may become conservative in granting credit. Therefore, in order to minimize non-performing loans at accepted levels, banks may avoid lending aggressively and violating the regulations of State Banks. Ultimately, banks may try to apply the international rules in management the loans, such as Basel and COSO.

Derived from information asymmetry theory, investment portfolio theory and moral hazard, the research took over approaches to the theory of the relationship between macro and micro factors that affect non-performing loan.

\section{(i) Theory of information asymmetric}

Information asymmetry is a disproportionate distribution of information and may have an impact on the decision-making process of both parties in the loan agreement (borrowers and lenders). Assume a business has a project that will be implemented in the future, and is looking for funds to raise capital to expand its business. Typically, it will approach the bank with a planned spreadsheet includes estimated cash outflows and inflows during the life of the project. In contrast to the bank, although, will try very carefully in the process of granting credit from the stage of appraisal to the stage of disbursement of loans. In fact, investors will always have better understanding of profits and risks in business than lenders (banks). Under asymmetric information, when the risks associated with the borrowers arise, the bank's profits will be greatly affected. The banks (lenders) again lack adequate data and information concerning the borrowers to assess accurately ( [24]).

The financing of a bank for a business can be considered as a simple funding contract between the two parties, in which the bank is the party granting loans and the business is the recipient and using the capital. However, the data and information that two parties supply to each other will lead to information asymmetry. Asymmetric information is growing in developing countries as information on credit quality of borrowers is limited because they do not have effective information management mechanisms and systems. Especially, there is no closely connection of information between banks. Credit rating agencies hardly exist in these countries, while credit reference agencies are still underdeveloped. 
The reason is due to information asymmetry between the borrowers and the lenders. Due to lack of information, banks often require customers to mortgage their assets. If asset prices fall, it will affect the balance sheet and net worth of the business. This reduces the ability to repay and negatively affects the investment. The channel operates through an external balance, reflecting the difference in the cost of external and internal capital. Derived from asymmetric information theory, the article has approached the theory of the relationship between macro factors as well as internal specificities (bank-specific factors) to non-performing loan, and combined with empirical studies before.

\section{(ii) Financial Accelerator effect}

Many researchers have demonstrated that macroeconomic conditions or business cycles have had a significant impact on non-performing loan. For example, [15] argues that changes in macroeconomic conditions are the most important system factor affecting bank losses. Based on the data of banks in Italy, [61] reported and provided empirical evidence that the business cycle affected non-performing loan. At the same time, researchers added dummy variables into their regression tissues to capture the business cycle. Moreover, the global financial crisis in 2008 had a strong negative impact on the financial sector. To control the impact of the global crisis, time trends are added to regression models.

When a macroeconomic shock occurs, the net asset value of the firm decreases, the direct effect will be caused by a change in the collateral of the borrower resulting in a change in credit provision. The bank uses it to lend to them, because now what banks look at is collateral that has reduced its value. Thus, from an initial shock of the economy has affected the credit market, which in particular reduced credit activity. Since then, non-performing loan will arise in the process of lending to customers with loans with reduced net asset value and reduced value of security assets.

\section{(iii) The quantity theory of money}

The theory of monetary quantity suggests that in the long run the amount of money does not depend on the size of the gross domestic product (GDP) but depends on the change in price or change in the general price level of the economy (inflation). There are two ways of interpreting monetary theory. The first way, using the cash balance equation, should be called the cash balance version. Cash balance theory was developed by a group of Cambridge economists such as Pigou, Marshall, Robertson and Keynes in the early 1900s. Economists argue that money works as a store of wealth and a means of giving change. Here, by cash balance and cash balance, is understood as the amount of money people want to hold rather than saving. According to Cambridge economists, people still want to hold cash to finance transactions and to ensure against unanticipated needs and risks. They also believe that an individual's cash demand or cash balance is proportional to that person's income. Obviously, the income of the individual is greater, the demand for cash or the balance of money is much higher.

Another way to use Fisher's exchange equation, is called the Number of Transaction Theory. Like the price of an item, the value of money is determined by money supply and money demand. In Fisher's theory of demand for money, Fisher emphasized the use of money as a means of exchange. In other words, money is required for trading purposes. According to Irving Fisher, under the condition that other factors remain unchanged, as the amount of money circulated increases, the price also increases in direct proportion and the value of money decreases and vice versa. If the amount doubled, the price would also double and the value of the money would be half. On the other hand, if the amount is halved, the price will also be halved and the value of the money will double. The theory of this amount of transactions can be expanded by including bank deposits in the form of money supply. Fisher considered GDP from a spending perspective, so Fisher's equation could be transformed into an equation to calculate the amount of cash demand to serve the spending needs of the economy. The total amount of money available in any economy in a given time is called money supply, there are many different forms to charge, and generally the money supply is divided into three types of Reserve (M0). : The total amount of cash issued by the central bank is circulating (Base money; Narrow money; Cash can be spent immediately). Money M1 is equal to M0 plus money that commercial banks deposit at the Central Bank. M2 money in M1 plus Standard currency (savings deposit, term deposit ... at credit institutions) (Money wide; Savings deposits cannot be spent immediately). M2 is the chosen target of money supply including two types before M0 and M1. The reserve shows the total amount of money available in tangible form while the narrow 
amount includes the reserve and all deposits required and the central bank's time. Besides, bank loans and credit are also one of the ways to increase money supply in the economy ( [26]).

\section{(iv) Bad luck hypothesis}

This hypothesis suggests that external circumstances (such as the decline of the economy) will make non-performing loans in the bank balance sheet increase. As a result, bank cost efficiency decreases due to increased operating costs to cope with higher NPLs. The importance of the unfortunate hypothesis is the inverse relationship between non-performing loan and the cost effectiveness that has been calculated. After these non-performing loans go into non-recoverable debts, banks begin to incur additional operating costs to settle and handle those debts. These additional costs may include: (1) additional monitoring of borrowers with their non-performing loans and collateral; (2) cost analysis and negotiation of feasible solutions; (3) final seizure, maintenance and handling costs for collateral in case of default; (4) costs of continuing to protect the bank's credit records in subsequent evaluations; and (5) divert management away from core business operations. These costs will increase as the bank's non-performing loans increase and thereby reduce the cost management efficiency of the bank itself significantly.

(v) Bad management hypothesis

The "poor management" hypothesis suggests that low-cost efficiency can represent poor management skills in managers' monitoring, supervision, control, which could lead to non-performing loan. Therefore, the "poor management" hypothesis implies the negative relationship between nonperforming loans, cost effectiveness. All "poor" managers mean (1) may appear to lack the ability to record, monitor and control credit, thereby providing a large number of valuable loans, current net negative; (2) incompetent to estimate the security value of the loan or (3) have difficulty controlling the borrower after granting them credit.

Low efficiency is a sign of poor management performance and will result in a large amount of undesirable loans ( [60]). According to this hypothesis, [13] argue that poor management of banks will lead to ineffective, ineffective and quality control of the bank itself (credit use) and from there will affect the lending process. From mismanagement leading to lax management in lending procedures and procedures, banks may not thoroughly evaluate customer credit records due to their poor assessment skills. Therefore, this leads to lower credit ratings for approved loans and high probability of nonperforming loans leading to higher non-performing loan rates. Inefficiencies in credit management of banks can lead to ineffective loans, or will result in non-performing loans.

(vi) Skimping hypothesis

Another hypothesis called skimping, extended by [13] and proposes a positive relationship between cost efficiency and non-performing loan. This is based on the fact that high cost efficiency can reflect how much of a bank's limited resources are allocated to tracking credit risk, and thus leads to a situation that can make debts Higher bad in the future. This hypothesis originates from the original idea proposed in monitoring can be significant for both the quality of the loan portfolio and the estimated cost effectiveness.

\section{(v) Too big to fail hypothesis}

The term "too big to go bankrupt" refers to organizations, the financial-banking system, businesses that are large and have a great influence on the economy, which forces governments to strengthen their support which is collapsed when any financial instability occurred, to avoid the implications for the economy. [72] in the report on banks "too big for bankruptcy" discussed this issue in the context of government policy on bankruptcy. They analyze the moral hazard problems that endanger the large financial institutions that policymakers consider "too big to go bankrupt." More specifically, if a large bank has many customers and these banks play an important role in the financial system, the collapse of that bank could threaten the solvency of other organizations. Related, this leads to a "domino" effect. The failure of this bank will become a major event and can then threaten to paralyze the entire economy. To avoid such a scenario, governments set up what [72] described as a defense policy for the so-called "too big for bankruptcy". The time after the financial crisis in 2008 - 2009 in the US, it was time for the Government to consider sponsoring some financial institutions to avoid collapse. Large financial institutions will be monitored and monitored closely and regularly. Some credit institutions are important institutions in the entire financial system and gain a certain competitive advantage. Provided that the 
economy is booming and growing strongly, and when the housing market collapses, it will be time to threaten their activities and lead to bankruptcy. That is when they become too big to collapse.

\subsection{Empirical research studies}

Table 1. Empirical studies of factors affect NPL

\begin{tabular}{|c|c|c|c|}
\hline Year & Author(s) & Independent variables/ results & Limitation \\
\hline 1980 & The US banks & Capital adequacy ratio (CAR) & The US banks \\
\hline & Japanese banks & $\begin{array}{l}\text { Implement well management of } \\
\text { capital and efficient internal control } \\
\rightarrow \text { sufficient capital to control } \\
\text { credit risk }\end{array}$ & $\begin{array}{l}\text { Macro factors are not } \\
\text { considered }\end{array}$ \\
\hline 2002 & Deutsche Bank & $\begin{array}{l}\text { Improve ROE } \rightarrow \text { Reduce credit } \\
\text { risk }\end{array}$ & Only ROE is considered \\
\hline 2004 & Godlewski & ROA $\rightarrow$ non-performing loan & Only ROA is considered \\
\hline 2008 & $\begin{array}{l}\text { Garciya-Marco and Robles- } \\
\text { Fernandez (2008) cited in } \\
\text { Mesai and Jouini (2013) }\end{array}$ & $\begin{array}{l}\text { ROE } \rightarrow \text { non-performing loan. The } \\
\text { higher ROE, the higher the risk. } \\
\text { The profit maximization policy is } \\
\text { accompanied by a high level of risk }\end{array}$ & Only ROE is considered \\
\hline $\begin{array}{l}2013 \\
2010 \\
2013 \\
2009\end{array}$ & $\begin{array}{l}\text { Messai and Jouini; } \\
\text { Louzis et al.; } \\
\text { Klein; } \\
\text { Boudriga. }\end{array}$ & $\begin{array}{l}\text { Macro and micro factors impact on } \\
\text { non-performing loan }\end{array}$ & \\
\hline 2011 & Louzis et al. & $\begin{array}{l}\text { A set of basic macroeconomic } \\
\text { indicators, namely, real GDP } \\
\text { growth rates, unemployment rates } \\
\text { and real interest rates }\end{array}$ & $\begin{array}{l}\text { The study of macro factors, not } \\
\text { considering the impact of } \\
\text { factors inside the banks }\end{array}$ \\
\hline 2011 & Zribi and Boujelbène & $\begin{array}{l}\text { (1) Bank characteristics: types of } \\
\text { ownership; (2) regulation on CAR; } \\
\text { (3) macro factors matrix; and (4) } \\
\text { bank size. }\end{array}$ & \\
\hline \multirow[t]{2}{*}{2012} & Bui Dieu Anh & $\begin{array}{l}\text { Did not conduct quantitative } \\
\text { research }\end{array}$ & \multirow{2}{*}{$\begin{array}{l}\text { Mainly doing research by } \\
\text { qualitative method. The } \\
\text { research achieved the theory of } \\
\text { loan portfolio management and } \\
\text { portfolio management method. } \\
\text { Analyzing the current status of } \\
\text { loan portfolio at Vietnam's } \\
\text { commercial banks. Refer and } \\
\text { generalize the models of credit } \\
\text { risk measurement, thereby } \\
\text { giving the process of credit risk } \\
\text { management and forming } \\
\text { factors affecting NPL ratio in } \\
\text { the expected model. }\end{array}$} \\
\hline & $\begin{array}{l}\text { Nguyen Tuan Anh } \\
\text { Nguyen Duc Tu } \\
\text { Nguyen Thi Hoai Phuong }\end{array}$ & $\begin{array}{l}\text { Did not build models to } \\
\text { perform regression and related } \\
\text { tests. Most focus on a specific } \\
\text { bank, except for the research of } \\
\text { author Nguyen Thi Hoai Phuong } \\
\text { focused on a group of } 5 \text { banks with } \\
\text { a large market share. }\end{array}$ & \\
\hline 2015 & Baholli et al. & $\begin{array}{l}\text { Albania and Italy: GDP, lending } \\
\text { interest rates, inflation, real } \\
\text { exchange rates are four } \\
\text { independent variables. The models } \\
\text { had explained the variation of } \\
\text { NPLs in Italy is around } 99 \% \text { and } \\
88 \% \text { for Albania. }\end{array}$ & $\begin{array}{l}\text { The impact of CAR, ROE, } \\
\text { Basel } 3 \text { factors has not been } \\
\text { considered. }\end{array}$ \\
\hline
\end{tabular}




\section{EVIDENCE IN VIETNAM}

\begin{tabular}{|c|c|c|c|}
\hline Year & Author(s) & Independent variables/ results & Limitation \\
\hline 2016 & Nguyen Thi Hong Vinh & $\begin{array}{l}\text { The average cost efficiency of } \\
\text { Vietnamese commercial banks is } \\
\text { measured by DEA data in the } \\
\text { research period reaching } 69.3 \% \text {. } \\
\text { Research for the first time } \\
\text { examines the negative relationship } \\
\text { between non-performing loan and } \\
\text { cost effectiveness of Vietnamese } \\
\text { commercial banks. The study found } \\
\text { evidence of the group had positive } \\
\text { and negative effect on NPL }\end{array}$ & \\
\hline 2017 & Kupčinskas and Paškevičius & $\begin{array}{l}\text { ROA, ROE, Net interest margin, } \\
\text { GDP, Unemployment rate, short- } \\
\text { term interest rate, Household } \\
\text { disposable income, Consumer price } \\
\text { index, Real estate price index }\end{array}$ & $\begin{array}{l}\text { The impact of CAR has not } \\
\text { been considered }\end{array}$ \\
\hline
\end{tabular}

Source: Author's collection

In summary, most studies have concentrated on the causes of NPL as well as assessed factors affecting NPL of commercial banks have been studied. However, there are still gaps in research on NPL because currently no research has conducted experiments and examined all macro and micro factors affect NPL and in terms of an entire banking system of a country, due to access restrictions and transparency of information.

The difference of this paper is (1) the use of theories of macro and micro factors affecting NPLs by quantitative research method of GMM with the existence of instrument variables. In addition, the study uses macro variables to make exogenous variables and specific variables as endogenous variables. (2) The results show a positive correlation in the relationship of bank efficiency (ROE, ROA) and NPL. Based on portfolio theory and investor risk tolerance to explain this result. The research model in the article shows that this result is completely contrary to the sign of effective banking relations and NPLs have been proved by studies such as Kwan and Eisenbeis [45], Hughes and Moon [32]. Studies by Kwan and Eisenbeis [45], Hughes and Moon [32] have shown that the more NPL is, the less the bank's efficient performance is.

In addition, corporate governance theory has been used to explain the negative relationship between leverage ratio and NPL ratio in this paper, instead of the hypothesis of "too big to fail". This result also shows a negative correlation in the relationship between the two these variables while previous studies of this relationship are in the same direction.

\section{RESEARCH METHODOLOGY AND PROPOSED MODEL}

On the basis of the analyzed theory, the article uses qualitative and quantitative methods combined with the case-study method to build the proposed model. The article includes a lag of the dependent variable in the model, which becomes an independent variable according to the theoretical research of the researchers. It is significant to include a lag of the dependent variable in the model if the study expects that the current level of the dependent variable is determined by its past level in a particular extent. In this case, if the model does not include the lag of the dependent variable, the estimation will be biased because the variable of lag is ignored and the results of the model may not be reliable.

For qualitative research, the author will point out the status of credit operations and the nonperforming loan ratio of Vietnamese commercial banks. The number of samples used is 32 commercial banks, including 4 state-owned commercial banks and 28 joint stock commercial banks (See Appendix 1 for the list of banks). In this article, the scope of deep research is two groups of state-owned commercial banks and joint stock commercial banks in Vietnam. Therefore, these banks represent both the stateowned commercial banks and commercial banks. The number of samples is $9 * 32=288$ observations. From the research results, the article will generalize and propose important management implications to 
help the whole banking system in our country operate more effectively. At the same time, the article uses the case in a research project of the author that has been criticized and published in the Science journal of Open University of Ho Chi Minh City as the basis for analysis.

Table 2. Summary of variables, hypotheses and related studies

\begin{tabular}{|c|c|c|c|c|}
\hline Variable & Code & Hypotheses & Sign & Related studies \\
\hline \multicolumn{5}{|c|}{ Dependent variable } \\
\hline $\begin{array}{l}\text { Non-performing } \\
\text { loan }\end{array}$ & NPLR & & & \\
\hline \multicolumn{5}{|c|}{ Independent variable } \\
\hline Latency of NPL & $\mathrm{NPLR}_{\mathrm{t}-1}$ & $\begin{array}{l}\text { latency of NPL has } \\
\text { positive effect on } \\
\text { NPL }\end{array}$ & + & $\begin{array}{l}\text { Chase et al. (2005); Kastrati (2011); Shingjergji } \\
\text { (2013b) }\end{array}$ \\
\hline $\begin{array}{l}\text { Capital } \\
\text { adequacy ratio }\end{array}$ & CAR & $\begin{array}{l}\text { CAR has negative } \\
\text { effect on NPL }\end{array}$ & - & $\begin{array}{l}\text { Sinkey and Greenawalt (1991); Shrives and } \\
\text { Dahl (1992); Afriyie and Akotey (2013) }\end{array}$ \\
\hline Bank size & SIZE & $\begin{array}{l}\text { Bank size has } \\
\text { negative effect on } \\
\text { NPL }\end{array}$ & - & $\begin{array}{l}\text { Michael C. Jensen (1976); Altman (2000); } \\
\text { Flamini (2009); Abdelkader et al. (2009) }\end{array}$ \\
\hline Internal control & $\mathrm{COSO}$ & $\begin{array}{l}\text { Internal control has } \\
\text { negative effect on } \\
\text { NPL }\end{array}$ & - & $\begin{array}{l}\text { Olatunji (2009); Lakis and Giriunas (2012); } \\
\text { Ellis và Jordi (2015); Ellis và Jordi (2016) }\end{array}$ \\
\hline $\begin{array}{l}\text { Operational } \\
\text { efficiency }\end{array}$ & $\begin{array}{l}\mathrm{ROA} \\
\mathrm{ROE}\end{array}$ & $\begin{array}{l}\text { Operational } \\
\text { efficiency has effect } \\
\text { on NPL }\end{array}$ & $+/-$ & $\begin{array}{l}\text { Jayadev (2006); Abdelkader et al. (2009); } \\
\text { Chang et al. (2009) }\end{array}$ \\
\hline $\begin{array}{l}\text { Loan to deposit } \\
\text { ratio }\end{array}$ & LDR & $\begin{array}{l}\text { LDR has negative } \\
\text { effect on NPL }\end{array}$ & - & $\begin{array}{l}\text { Van den End (2016); Jameel (2014); Anjom } \\
\text { and Karim (2015) }\end{array}$ \\
\hline $\begin{array}{l}\text { Loan loss } \\
\text { provision } \\
\end{array}$ & LLP & $\begin{array}{l}\text { LLP has positive } \\
\text { effect on NPL }\end{array}$ & + & $\begin{array}{l}\text { Boudriga et al. (2010); Radivojevic and } \\
\text { Jovovic (2017) }\end{array}$ \\
\hline Leverage ratio & LEVERAGE & $\begin{array}{l}\text { Leverage ratio has } \\
\text { positive effect on } \\
\text { NPL }\end{array}$ & + & $\begin{array}{l}\text { Radivojevic and Jovovic (2017); Muratbek } \\
\text { (2017) }\end{array}$ \\
\hline Liquidity ratio & LIQUIDITY & $\begin{array}{l}\text { Liquidity ratio has } \\
\text { negative effect on } \\
\text { NPL }\end{array}$ & - & Van den End (2016); Ozili (2017) \\
\hline Loan growth & GR_LOAN & $\begin{array}{l}\text { Loan growth has } \\
\text { positive effect on } \\
\text { NPL }\end{array}$ & + & $\begin{array}{l}\text { Cavallo and Majnoni (2001); Khemraj and } \\
\text { Pasha (2009); Guy and Lowe (2011); Rahaman } \\
\text { and et al. (2014) }\end{array}$ \\
\hline $\begin{array}{l}\text { Cost to income } \\
\text { ratio }\end{array}$ & CIR & $\begin{array}{l}\text { LLP has negative } \\
\text { effect on NPL }\end{array}$ & - & $\begin{array}{l}\text { Fan and Shaffer (2004); Altunbas, Carbo, } \\
\text { Gardener and Molyneux (2007); Lin and Zhang } \\
\text { (2009); Karim et al. (2010); Louzis et al. } \\
\text { (2012) }\end{array}$ \\
\hline Inflation ratio & INF & $\begin{array}{l}\text { INF has positive } \\
\text { effect on NPL }\end{array}$ & + & $\begin{array}{l}\text { Michael F. Bryan (1997); Joseph T. Salerno } \\
\text { (1987) }\end{array}$ \\
\hline GDP growth & GDP & $\begin{array}{l}\text { GDP growth has } \\
\text { negative effect on } \\
\text { NPL }\end{array}$ & - & $\begin{array}{l}\text { Hippolyte Fofack (2005); Koopman and Lucas } \\
\text { (2005); Yiping Qu (2008); Waweru and Kalani } \\
(2009)\end{array}$ \\
\hline $\begin{array}{l}\text { Money supply } \\
\text { (M2) }\end{array}$ & M2 & $\begin{array}{l}\text { M2 has negative } \\
\text { effect on NPL }\end{array}$ & - & $\begin{array}{l}\text { Ahmad (2003); Badar and Yasmin (2013); } \\
\text { Berhani and Ryskulov (2014) }\end{array}$ \\
\hline
\end{tabular}

In addition, quantitative research methods are used to build models to achieve the expected objectives. The model includes the $\mathrm{NPL}_{\mathrm{it}-1}$ variable. This means the model is a Dynamics Panel Model, in which the NPL $\mathrm{it}_{\mathrm{it}}$ variable is correlated with the residual, in other words the model has an endogenous phenomenon in the NPL $\mathrm{Nit}_{-1}$ variable. In this case, the least squares estimation methods such as Pooled OLS, FEM (Fixed Effects Model) and REM (Random Effects Model) are unstable and biased. With 
unstable and biased estimates, we cannot interpret the results of the model accurately and reliably. In order to solve this phenomenon, the research team used System Generalized Method of Moments (System GMM) according to Arellano and Bond [4]. Arellano-Bond's approach was first proposed by Ahmad [1], where the tool variable would include the lag variables of endogenous variables (in this case $\mathrm{NPL}_{\mathrm{it}-1}$ and the difference of explanatory variables). By this method, the endogenous variation will be determined in the model, therefore it is no longer correlated with the residual of the model.

From the analysis of the theories and previous research studies, the article builds the following model as:

$\mathbf{N P L}_{\mathrm{it}}=\beta_{1}+\beta_{2} * \mathrm{NPL}_{\mathrm{it}-1}+\beta_{3} * \mathrm{CAR}_{\mathrm{it}}+\beta_{4} * \mathrm{SIZE}_{\mathrm{it}}+\boldsymbol{\beta}_{5} * \mathrm{COSO}_{\mathrm{it}}+\boldsymbol{\beta}_{6} * \mathbf{R O A}_{\mathrm{it}}+\boldsymbol{\beta}_{7} * \mathbf{R O E}_{\mathrm{it}}+\boldsymbol{\beta}_{8} *$ $\mathbf{L D R}_{\mathrm{it}}+\boldsymbol{\beta}_{9} * \mathbf{L L P}_{\mathrm{it}}+\boldsymbol{\beta}_{10} *$ Leverage ratio $_{\mathrm{it}}+\boldsymbol{\beta}_{11} * \mathbf{L i q u i d i t y}$ ratio $_{\mathrm{it}}+\boldsymbol{\beta}_{12} * \mathbf{C I R}_{\mathrm{it}}+\boldsymbol{\beta}_{13} * \mathrm{INF}_{\mathrm{it}}+\boldsymbol{\beta}_{14} *$ GDP $_{\text {it }}++\beta_{15} *$ GR_LOAN ${ }_{\text {it }}+\beta_{16} *$ M2 $+u_{\text {it }}$

$\mathrm{NPL}_{\text {it }}=$ Non-perfoming loan of bank i

$\mathrm{NPL}_{\mathrm{it}-1}=$ the latency of non-performing loan $\mathrm{t}-1$

$\mathrm{CAR}=$ capital adequacy ratio

SIZE $=$ bank size

$\mathrm{COSO}=$ internal control

ROA = operational efficiency

$\mathrm{ROE}=$ operational efficiency

$\mathrm{LDR}=$ loan to deposit ratio

LLP $=$ loan loss provision

GR_LOAN = loan growth

$\mathrm{CIR}=$ cost to income ratio

$\mathrm{INF}=$ inflation ratio

$\mathrm{GDP}=$ gross domestic product's growth

M2 = money supply's growth

$n \mathrm{nlr}_{\text {it }}=\mathrm{f}\left(\mathrm{nplr}_{\mathrm{it}}\right.$, inf, gdp, $\mathrm{m} 2$, roe, coso, llp, car, growth_loan, leverage, liquidity, size, cir) [Model 1]

$\mathrm{nplr}_{\mathrm{it}}=\mathrm{f}\left(\mathrm{nplr} \mathrm{it}_{\mathrm{it}}\right.$, inf, gdp, m2, roa, coso, llp, car, growth_loan, leverage, liquidity, size, cir) [Model 2]

The summary of measurement for variables in the model, and their expected signs as well as relevant empirical studies is shown in Table 2.

\section{RESEARCH RESULTS}

Table 3. Descriptive statistics of model 1

\begin{tabular}{cccccc}
\hline \hline Variable & Obs & Mean & Std. dev & Min & Max \\
\hline nplr & 201 & 0.0233402 & 0.0154478 & 0.00008 & 0.11402 \\
roe & 201 & 0.1019811 & 0.0698966 & 0.00068 & 0.29201 \\
ca_compliance & 201 & 0.9465914 & 0.7641957 & 0.37187 & 10.41285 \\
llp & 201 & 0.0134815 & 0.0056552 & 0.002936 & 0.032673 \\
car & 201 & 0.1440572 & 0.0601032 & 0.064 & 0.4511 \\
gr_loan & 201 & 0.2777522 & 0.2590509 & -0.2218 & 1.4806 \\
inf & 201 & 0.0720846 & 0.0511457 & 0.006 & 0.187 \\
size & 201 & 32.1791 & 1.219738 & 29 & 35 \\
m2 & 201 & 122.5894 & 18.69442 & 99.79859 & 155.2222 \\
cir & 201 & -0.5177248 & 0.1337024 & -1.115236 & -0.225069 \\
leverage & 201 & 11.11459 & 4.464349 & 2.008499 & 27.87601
\end{tabular}

Source: results from Stata 
Firstly, the study will perform descriptive statistics results. From the descriptive statistics in Table 3, we see the smallest value of the variable "nplr" is 0.00008 , the maximum value is 0.11402 while the average value is 0.0233402. Accordingly, the highest NPL ratio is of Saigon Commercial Joint Stock Bank (SCB) in 2010 and the lowest NPL ratio is of Bao Viet Commercial Joint Stock Bank - BVB (2010) which is 0.00008 . The volatility level of the NPL ratio is 0.0154478 . The remaining variables have reasonable average, minimum and maximum values.

In the next step, the study tests the defects of the function form, including the phenomenon of autocorrelation, the phenomenon of multicollinearity and the phenomenon of variance change.

Table 4. Collinearity Test Results of model 1

\begin{tabular}{ccc}
\hline Variable & VIF & $\mathbf{1 / V I F}$ \\
\hline m2 & 6.27 & 0.159589 \\
inf & 3.86 & 0.258874 \\
size & 3.06 & 0.327118 \\
leverage & 2.92 & 0.342414 \\
gdp & 2.58 & 0.388326 \\
roe & 2.45 & 0.407956 \\
cir & 2.15 & 0.464336 \\
car & 1.93 & 0.519368 \\
gr_loan & 1.47 & 0.679313 \\
llp & 1.35 & 0.738724 \\
ca_compliance & 1.09 & 0.91905 \\
Mean VIF & 2.65 & \\
\hline
\end{tabular}

Source: results from Stata

According to Table 4, the VIF coefficients are all smaller than 10, so the multicollinearity phenomenon does not exist in the model. Reference [5] suggested that the VIF coefficient less than 10 is acceptable. General principles: If any VIF value exceeds 10, it means that the relevant regression coefficients are estimated to be ineffective due to multicollinearity phenomenon.

Table 5. Correlation matrix

\begin{tabular}{|c|c|c|c|c|c|c|c|c|c|c|c|}
\hline & nplr & roe & $\underset{\text { compliance }}{\mathrm{ca}_{-}}$ & $11 \mathrm{p}$ & car & $\begin{array}{l}\mathrm{gr}_{-} \\
\text {loan }\end{array}$ & $\inf$ & size & $\mathrm{m} 2$ & cir & leverage \\
\hline nplr & 1 & & & & & & & & & & \\
\hline roe & -0.2628 & 1 & & & & & & & & & \\
\hline $\begin{array}{c}\mathrm{ca}_{-} \\
\text {compliance }\end{array}$ & -0.0286 & 0.0020 & 1 & & & & & & & & \\
\hline $11 \mathrm{p}$ & 0.5697 & 0.0204 & -0.1919 & 1 & & & & & & & \\
\hline car & 0.1859 & -0.2586 & 0.0032 & -0.1248 & 1 & & & & & & \\
\hline gr_loan & -0.2403 & 0.2336 & -0.0078 & -0.2991 & 0.0973 & 1 & & & & & \\
\hline inf & 0.0731 & 0.2790 & 0.1376 & 0.0184 & 0.0743 & -0.0303 & 1 & & & & \\
\hline size & -0.1337 & 0.3049 & -0.0408 & 0.2685 & -0.5946 & -0.2106 & -0.1797 & 1 & & & \\
\hline $\mathrm{m} 2$ & -0.1697 & -0.1972 & -0.0943 & -0.0968 & -0.1196 & -0.1328 & -0.7714 & 0.2854 & 1 & & \\
\hline $\operatorname{cir}$ & -0.2721 & 0.6954 & 0.0287 & -0.0356 & -0.0702 & 0.2677 & 0.2450 & 0.1149 & -0.1895 & 1 & \\
\hline leverage & -0.1846 & 0.2380 & -0.0785 & 0.1032 & -0.6546 & -0.0352 & -0.1661 & 0.7370 & 0.2605 & 0.0009 & 1 \\
\hline
\end{tabular}

According to the result of the correlation matrix (Table 5), after eliminating the variables with a correlation coefficient greater than 0.8 and the remaining correlation coefficients are smaller than 0.8 , the 
EVIDENCE IN VIETNAM

model is free of multicollinearity phenomenon. Next, the study carried out test of the variance change phenomenon with the results shown in Table 6:

Table 6. Test for heteroskedasticity

\footnotetext{
Ho: Constant variance

Variables: fitted values of nplr

$\operatorname{chi} 2(1)=94.80$

Prob $>$ chi $2=\mathbf{0 . 0 0 0 0}$
}

Breusch-Pagan / Cook-Weisberg test for heteroskedasticity

Source: results from Stata

According to table 6 , p-value $=0,0000$ less than $5 \%$, so $\mathrm{H} 0$ is rejected. It means that the variance is not constant. After testing for heteroskedasticity, the paper will continue to test the autocorrelation with the results presented in the following table:

Table 7. Test for autocorrelation in panel data (model 1)

\section{Wooldridge test for autocorrelation in panel data}

H0: no first-order autocorrelation

$\mathrm{F}(1,27)=7.616$

Prob $>\mathrm{F}=\mathbf{0 . 0 1 0 3}$

Source: results from Stata

Table 7 shows that p-value in the autocorrelation test is 0.0103 which is less than 0.05 so H0 is rejected, which means there is an autocorrelation in model 1 . When the model has autocorrelation, the study proposes using Dynamic panel data to remove it. This means the dependent variable of Nonperforming loan of this year will be affected by another independent variable, which is the lag variable (the non-performing loan of the previous year) and the tool variables. To solve the defects of model 1 (the autocorrelation phenomenon and the endogenous phenomenon), the GMM estimation method is used:

Table 8. Sargan test for model 1

\section{Sargan test of overidentifying restrictions}

H0: overidentifying restrictions are valid

$\operatorname{chi} 2(97)=105.7848$

Prob $>$ chi $2=\mathbf{0 . 2 5 4 6}$

Source: results from Stata

Because the model has the lag variable, it is impossible to apply OLS estimation but the GMM estimation with instruments variables is used. The dynamic model is estimated by GMM (Generalized Method of Moments), introduced by Arellano and Bond [4]. This selection of estimation is consistent with empirical studies by De Bock and Demyanets [5]. According to Arellano and Bond [4], the autocorrelation phenomenon between the lag of the dependent variable and the error can be solved by adding tool variables to the dynamic panel data model. At this point, the model has been completely free of defects such as phenomenons of multicollinearity, variance change and self-correlation due to the use of GMM estimation method. In this model, as can be seen in Table 8, the p-value in Sargan test (with the 
assumption "H0: over identifying restrictions are valid") is large (p-value $=0.2546$ ), so there is not enough evidence to reject the hypothesis H0. Therefore, the GMM estimation method is valuable.

Table 9. Results for model 1 from GMM method

\begin{tabular}{ccc}
\hline Variable & Coefficient & p-value \\
\hline nplr L1. & -0.14461958 & $0.021^{*}$ \\
Inf & -0.01099994 & 0.687 \\
Gdp & -0.9766966 & $0.000^{* * *}$ \\
m2 & 0.00007445 & 0.429 \\
Roe & 0.04805026 & $0.020^{*}$ \\
ca_compliance & 0.00183776 & 0.450 \\
Llp & 1.4854596 & $0.000^{* * *}$ \\
Car & -0.00934383 & 0.720 \\
gr_loan & 0.00435189 & 0.315 \\
Size & 0.00032974 & 0.886 \\
Cir & -0.02315912 & $0.025^{*}$ \\
Leverage & -0.00078282 & $0.048^{*}$ \\
cons & 0.03764531 & 0.595 \\
\end{tabular}

With results from Table 9, the model has six variables with statistical significance including variable of "nplr L1", variable of "inf" and variable of "roe" because the p-value of these variables are less than 5\%. According to Ahmad [1], by the estimation of the parameters of the model using General least squares, the total number of squares cannot be broken down by Ordinary Least Square (OLS), because it will make the statistics of R-squared less useful when choosing the diagnostic tool that allows GLS regression. Specifically, for a statistic of R-squared calculated from GLS, the sum of squares does not need to be limited between 0 and 1 ; and does not represent the percentage of variation of the dependent variable in the model. In addition, removing or adding variables in a model does not always increase or decrease the calculated value of R2. Since the GMM method is used for estimating the dynamic panel model with instrument variables, $\mathrm{R} 2$ is not meaningful to evaluate research results.

Empirical results deriving from Model 2 which employs ROA instead of ROE are displayed in Table 10 and Table 11.

Table 10. Sargan test for model 2

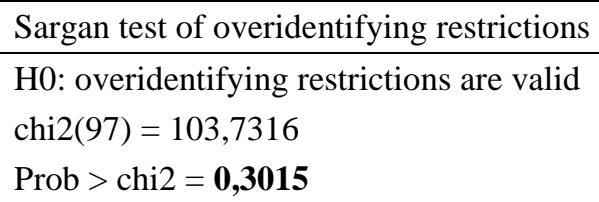

\section{DISCUSSION}

The rationality of the tool variables used in the GMM model was proved through two tests including the endogenous test of Sargan [58] and the autocorrelation test of Arellano - Bond [4]. Endogenous test in Sargan's model [58] with the hypothesis "H0: instrument variables are exogenous (not correlated with error)". The larger the result of the p value of Sargan statistics, the better. Test of autocorrelation in the model of Arellano - Bond [4] with hypothesis H0: there is no autocorrelation with the error. In this study, the $\mathrm{p}$-value in the Sargan test is large ( $\mathrm{p}$-value $=0.2546$ in model 1 and $\mathrm{p}$-value $=0.3015$ in model 2 ) so the estimation method GMM is valuable. 
Variables of Gross domestic product growth rate, LLP and Cost on income ratio are statistically significance in both cases where the model has independent variable of ROE and the model has independent variable of ROA.

In the article, the variable of GDP growth rate is not statistically significant, but has negative value and is consistent with initial expectations. Besides, the research results of the article are also consistent with previous studies such as Salas and Saurina [64]; Jimenez and Saurina [37]; Khemraj and Pasha [42]. This result is given in the empirical literature and proves that higher real GDP growth often leads to higher income levels.

Table 11. Results for model 2 from GMM method

\begin{tabular}{ccc}
\hline Variable & Coefficient & p-value \\
\hline nplr L1. & -0.1418234 & $0.025^{*}$ \\
Inf & -0.011048 & 0.692 \\
Gdp & -0.9432081 & $0.000^{* * *}$ \\
m2 & 0.0000655 & 0.494 \\
Roa & 0.5166915 & $0.040^{*}$ \\
ca_compliance & 0.0018006 & 0.463 \\
Llp & 1.477107 & $0.000^{* * *}$ \\
Car & -0.0122391 & 0.646 \\
gr_loan & 0.0042792 & 0.330 \\
Size & 0.0001465 & 0.949 \\
Cir & -0.024575 & $0.028 *$ \\
Leverage & -0.0004463 & 0.250 \\
cons & 0.0388784 & 0.582 \\
\hline
\end{tabular}
Most of researches done on banks emphasized the profitability of the organization related to return on equity (ROE) and return on assets (ROA). Return on equity and return on assets show the efficiency of banks in generating income by using equity and assets. High performing banks (ROA) and high profitability (ROE) have less pressure on making profits, so they are less dependent on venture capital in high risky projects. At the same time, low ROE of ineffective banks is related to high NPL ratio. Many studies show a negative relationship between ROA, ROE and Non-performing loan as studies by Warue (2013), Makri et al. [50], Radivojevic and Jovovic [62], Kumar et al. [44]. However, the research results show that ROE and ROA have the positive relationship with NPLs. The results of the paper are consistent with some previous studies conducted by Godlewski [29] and Stakic [71]. These authors have confirmed these issues. Particularly, when net profit on equity or / and net profit on total assets increases, nonperforming loan in the credit granting process to customer also increases. Several other studies conducted by Garsiya and Fernandez [27] show that high ROA and ROE lead to a higher level of risk. In addition, determined the positive correlation between the variables of ROE and ROA and the NPLs that is mentioned above. From the perspective of portfolio theory, profits and risks, finance investors are classified into three types of attitudes to risk: risk aversion investors, risk indifference investors and risk preference investors. When investors make decision on their investment behavior, they often consider the relationship between profit and risk. If two investment opportunities offer the same expected rate of return, the investor will choose the one has lower risk. Otherwise, if two investment opportunities have the same level of risk, the investor will choose to invest in the one with a higher expected return. Finally, for risk aversion investors, if they invest in projects with high risks, in addition to the rate of profit received, they definitely require for an additional risk premium (risk premium) to offset.

The variable of the reserve rate is statistically significant at $0.1 \%$ and is consistent with the initial expectation of the study. That means the reserve rate has a positive relationship with non-performing loan. The results are consistent with the researches of Hasan and Wall [30]; Messai and Jouini [51]; Radivojevic and Jovovic [62].

The variable of the cost on income ratio is statistically significant in both model 1 and model 2 because the p-value is less than 5\%. However, the model's research results show that the relationship 
between the cost on income ratio and the non-performing loan ratio is negative, while the initial expectation mark on this relationship is positive. This ratio measures the bank's management efficiency (Ozili [58]; Lin and Zhang [48]. For management indicators, when banks manage cost effectively and maintain the ratio of operating costs on operating incomes less than 1, NPLs will decrease. Effective banks have lower NPL ratios than inefficient banks (Louzis et al. [49]; Karim et al. [39]). Some studies have found an inverse relationship between the efficiency of operating cost management and the nonperforming loan problem of banks (Kwan and Eisenbeis [45]). The positive relationship between asset quality and cost effectiveness (DeYoung [22]) suggests a negative relationship between non-performing loan and cost effectiveness. The results are consistent with previous studies such as Lin and Zhang [48]; Karim et al. [39]; Louzis et al. [49]. Management effectiveness and the hypothesis of Poor management prove a negative relationship with statistical significance between non-performing loan and cost management effectiveness. The results of the paper are consistent with the conclusions of Louzis et al. [49]; Chaibi and Ftiti [16].

The difference between model 1 and model 2 is the Leverage ratio. In model 1, the variable of leverage ratio is statistically significant at $95 \%$ confidence level, while in model 2 , this variable is not statistically significant. Leverage (as required by Basel III), can bring advantages to banks in mobilizing shareholders' capital to raise capital. Basel Committee continued to verify the minimum requirement of 3\% for leverage ratio from January 1, 2013 to January 1, 2017. According to Basel III, tier 1 capital must have at least $3 \%$ of total assets without risk. The leverage ratio of the banking industry also has a significant impact on non-performing loans. There is a positive and significant correlation between leverage and non-performing loan (Chaibi and Ftiti [16]; Louzis et al., 2011 and Muratbek [53]). They argue that debt-to-asset ratio is a factor of non-performing loan in the "too big to bust" hypothesis that significantly affects the bank's risk. However, the research results of the article have differences in the correlation between leverage ratio and non-performing loan. According to the results of the research model, the correlation is negative and the result of this relationship is contrary to previous empirical studies. This relationship can be explained by the corporate management mechanism. Corporate management is a part of the mechanism to describe and evaluate the performance of an organization as well as the reliability of organizational management, especially in the current dynamic and globalized economic environment where organizations need to constantly seek new business opportunities to improve their competitiveness and performance (Suhaimi et al., 2017). Poor corporate management - for example, lack of responsibility for work, lack of risk management skills, low corporate social responsibility, tax non-compliance and weak internal control - increase risks to organizations, then reduces the reputation of the organization and increases fraud and moral hazard behaviors (Nawawi et al., 2018; Karim et al. [39]; Amirudin et al. [3]; Salin et al. [73]; Rahim et al. [63]; Omar et al. [57]; Salin and Abidin [67]). The effective corporate management mechanism will promote the transparency and credibility as well as improve the quality of financial statements, thereby improving investment efficiency (Salin et al. [73]; Jais et al. [35]; Husnin et al. [33]). This suggests that good corporate management will lead to more effective economy and investment decisions and indirectly increase the value of the company. Previous empirical studies have demonstrated the importance of the corporate management mechanism that is important in managing non-performing loans (Ahmad et al. [1]). The Basel Committee on Banking Supervision (BCBS) [9] emphasized that effective corporate management is essential to achieve and maintain public confidence in the banking system. So far, most researches have focused on developed countries and not many of them talked about corporate mangement and its role in the banking industry. Donaldson [23] asserts that corporate management is the mechanism in which the highest level of management within an organization belongs to the board management through monitoring programs and other binding policies. Tricker [74] also argues that a management board should include the owner and all those interested in the work or financial situation of a company such as creditors, loan mobilizers, analysts, and business managers. Shleifer and Vishny [70] argue that a specific corporate management mechanism shows how the sponsors (creditors, shareholders, investors, etc.) of the company ensure they can receive income from their investments. Monks and Minow [52] argue that corporate management is the relationship between different participants of an organization, affecting the operation direction and effectiveness of the corporation. Therefore, when a leverage rate is high, that means the bank has 
increased the level of debt use from outside entities. According to corporate management theory, creditors or related parties will have mechanisms to closely control and monitor, even participate in the bank's board of directors to monitor and supervise how the bank use loans to ensure the best business performance and profitability. One of the most profitable investment activities of banks is customer lending, so under such strict monitoring and supervision mechanisms, banks are forced to be more cautious in granting credit to customers to improve their business performance. This means banks will reduce non-performing loans incurred in the process of credit granting to customers at the lowest possible level.

\section{CONCLUSION}

Based on the qualitative and quantitative research methods, the paper has built a model that includes the main factors affecting non-performing loans in Vietnam's commercial banks in the period of 2009 2017. Research results of two models show that model 1 has six statistically significant variables while model 2 has five variables with statistical significance. Thus, the main factors affecting non-performing loan include non-performing loan ratio of the previous year, GDP growth, net profit on equity, net profit on assets, loan loss provision, cost to income ratio, and leverage ratio.

\section{REFERENCES}

[1] Ahmad, M. I., Guohui, W., Hassan, M., Naseem, M. A., and Rehman, R., NPL and Corporate Governance: A Case of Banking Sector of Pakistan. Accounting and Finance Research, 5(2), 32-41, 2016.

[2] Ahmad, N. M. N. N., Nawawi, A., and Salin, A. S. A. P., The relationship between human capital characteristics and directors' remuneration of Malaysian public listed companies. International Journal of Business and Society, 17(2), 347-364, 2016.

[3] Amirudin, N. R., Nawawi, A., and Salin, A. S. A. P., Risk management practices in tourism industry - A case study of resort management. Management and Accounting Review, 16(1), 55-74, 2017.

[4] Arellano, M. and Bond, S., Some Tests of Specification for Panel Data: Monte Carlo Evidence and an Application to Employment Equations. The Review of Economic Studies, 58(2), 277-297, 1991.

[5] Asmuni, A. I. H, Nawawi, A. and Salin, A. S. A. P., Ownership structure and auditor's ethnicity of Malaysian public listed companies. Pertanika Journal of Social Science and Humanities, 23(3), 603-622, 2015.

[6] Baholli, F., Dika, I., \& Xhabija, G., Analysis of Factors that Influence Non-Performing Loans with Econometric Model: Albanian Case. Mediterranean Journal of Social Sciences, 6(1), 391-398, 2015.

[7] Basel, Principles for the management of credit risk Consultive paper issued by Basel Committee on Banking Supervision. Basel, 1999.

[8] Basel Committee on Banking supervision., Sound credit risk assessment and evaluation for loans. Switzerland: BIS Press and Communication, Basel, 2006.

[9] Basel Committee on Banking Supervision., Principles for enhancing corporate governance. Switzerland: Bank for international settlements, 2010.

[10] Basel Committee On Banking Supervision., Principles for enhancing corporate governance, 2010.

[11]Berg, S. A., Forsund, F. and Jansen, E., Malmquist indices of productivity growth during the deregulation of Norwegian banking, 1980-89. Scandinavian Journal of Economics 94, S221-S228, 1992.

[12] Berger, A., The relationship between capital and earnings in banking. Journal of Money, Credit and Banking, 27(2), 432-456, 1995. 
[13] Berger, A. N. \& DeYoung, R., Problem Loans and Cost Efficiency in Commercial Banks. Journal of Banking and Finance, 21, 849-870, 1997.

[14] Berhani, R. and Ryskulov, U., Macroeconomic Determinants of Nonperforming Loans in Albanian Banking System. International Conference on Economic and Social Studies. International Burch University, Sarajevo, 2014.

[15] Carey, M., Credit Risk in Private Debt Portfolios. Journal of Finance, 53(4), 1363-1387, 1998.

[16] Chaibi, H. and Ftiti, Z., Credit risk determinants: Evidence from a cross-country study. Research in international business and finance, 33, 1-16, 2015.

[17] Chen, F., Hope, O. K., Li, Q. and Wang, X., Financial reporting quality and investment efficiency of private firm in emerging markets. The Accounting Review, 86(4), 1255-1288, 2011, 2011.

[18] Chính phủ, Nghị định Số: 53/2013/NĐ-CP., Về Thành Lập, Tổ Chức And Hoạt Động Của Công Ty Quản Lý Tài Sản Của Các Tổ Chức Tín Dụng Việt Nam. Hà Nội: Chính phủ, 2013.

[19] Chính phủ, Nghị định Số: 18/2016/NĐ-CP., Sửa Đổi, Bổ Sung Một Số Điều Của Nghị Định Số 53/2013/Nđ-Cp Ngày 18 Tháng 5 Năm 2013 Của Chính Phủ Về Thành Lập, Tổ Chức And Hoạt Động Của Công Ty Quản Lý Tài Sản Của Các Tổ Chức Tín Dụng Việt Nam. Hà Nội: Chính phủ, 2016.

[20] COSO. (), Internal Control-Integrated Framework. New York: AICPA, 1992.

[21]Dash, M. and Kabra, G., The determinants of non-performing assets in Indian commercial bank: An econometric study. Middle Eastern Finance and Economics, 7, 94-106, 2010.

[22]DeYoung, R., X-Efficiency and Management Quality in National Banks. Journal of Financial Services Research, 1997.

[23] Donaldson, L. (), The ethereal hand, organisational economies and management theory. Academy of Management Review, 15(3), 369-81, 1990.

[24]Edwards, P. and Turnbull, A., Finance for small and medium sized enterprises. Information and the income gearing challenge. International Journal of marketing, 12(6), 3-9, 1994.

[25]Ellis, Kofi Akwaa-Sekyi., \& Jordi, Moreno Gené., Effect of internal controls on credit risk among listed Spanish banks. Intangible Capital, 13(1), 25-50, 2015, 2015.

[26]Felix, A. Takang and Cloudine, Ntui., Bank Performance and credit Risk Management. Master thesis. University of Skovde, 2008.

[27] Garsiya, M. T. and Fernandez, R. M. D., Risk-Taking Behaviour and Ownership in the Banking Industry: The Spanish Evidence. Journal of Economics and Business, 60(4), 332-354, 2007.

[28] Godlewski, C., Capital Regulation and Credit Risk Taking: Empirical Evidence from Banks in Emerging Market Economies. Finance 0409030, EconWPA, 2004.

[29] Godlewski, C., Capital Regulation and Credit Risk Taking: Empirical Evidence from Banks in Emerging Market Economies. Finance 0409030, EconWPA, 2004.

[30] Hasan, I. and Wall, L.D., Determinants of the loan loss allowance: some cross-country comparison. The Financial Review, 29(1), 129-152, 2004.

[31] Hess, K. and Francis, G., Cost income ratio benchmarking in banking. Benchmarking: An International Journal, 3, 303-319, 2004. 
[32] Hughes, J.P. and Moon, C. G., Measuring bank efficiency when managers trade return for reduced risk. Department of Economics, Rutgers University, 1995.

[33] Husnin, A. I., Nawawi, A., and Salin, A. S. A. P., Corporate governance and auditor quality - Malaysian evidence. Asian Review of Accounting, 24(2), 202 - 230, 2016.

[34] IMF. Lessons of the global crisis for macroeconomic policy. IMF Staff Paper No. 09/37. Washington, DC: International Monetary Fund, 2006.

[35] Jais, K. M., Nawawi, A., and Salin, A. S. A. P., Reduction of audit quality by auditors of small and medium size audit firms in Malaysia: A case of premature sign-off of audit documents. Journal of Accounting, Business \& Management, 23(2), 1-12, 2016.

[36] Jensen, Michael C. \& Meckling, William H., Theory of the firm: Managerial behavior, agency costs and ownership structure. Journal of Financial Economics, 3(4), 305-360, 1976.

[37] Jimenez, G. and Saurina, J., Credit cycles, credit risk, and prudential regulation. International Journal of Central Banking, 43(1), 65-98, 2006.

[38] Jovovic, J., Determinants of Non-Performing Loans: Econometric Evidence Based on 25 Countries. Master thesis. City University London, 2014.

[39] Karim, N.A., Nawawi, A. and Salin, A. S. A. P., Inventory control weaknesses - A case study of lubricant manufacturing company. Journal of Financial Crime, 25(2), 436-449, 2018.

[40] Kastrati, A., The Determinants of Non-Performing Loans in Transition Countries. Financial Stability Report, Central Bank of the Republic of Kosovo , 97-102, 2011.

[41] Keeton, W. and Morris, C., “Why Do Banks' Loan Losses Differ?” Federal Reserve Bank of Kansas City. Economic Review, 3-21, 1987.

[42] Khemraj, T. and Pasha, S., The determinants of non-performing loans: An econometric case study of Guyana. The Caribbean Centre for Banking and Finance Bi-annual Conference on Banking and Finance, St. Augustine, Trinidad, 2009.

[43] Klein, N., Non-performing loans in CESEE: Determinants and impact on macroeconomic performance. IMF Working Paper. WP13/72. IMF, 2013.

[44] Kumar, S., Das, B. R. and Mohanty, A. R., Determinants of Non-Performing Loans in India: A System GMM Panel Approach. Prajnan, 38-56, 2018.

[45] Kwan, S. and Eisenbeis, R.A., Bank risk, capitalization and operating efficiency. Journal Financial Services Res, 12, 117-131, 1997.

[46]Lakis, V. and Giriunas, L., The concept of internal control system: Theoretical aspect. Ekonomika 2012, 91(2), 142-152, 2012.

[47]Lee, C. and Hsieh, M. (), The impact of capital on profitability and risk in Asian banking. Journal of International Money Finance, 32(2), 251-281, 2013.

[48]Lin, X.C. and Zhang, Y., Bank ownership reform and bank performance in China. Journal of Banking \& Finance, 58, 131-143, 2009.

[49]Louzis, D. P., Vouldis, A. T., and Metaxas, V. L., Macroeconomic and bank-specific determinants of nonperforming loans in Greece: a comparative study of mortgage, business and consumer loan portfolios. Journal of Banking and Finance, 36, 1012-1027, 2011. 
[50] Makri, V., Tsagkanos, A., \& Bellas, A., Determinants of non-performing loans: The case of Eurozone. Panoeconomicus, 61(2), 193-206, 2014.

[51] Messai, A. S. \& Jouini, F. (), Micro and Macro Determinants of Non-performing Loans. International Journal of Economics and Financial Issues, 3(4), 852-860, 2013.

[52] Monks, R.A.G., and Minow, N., Corporate Governance. Blackwell, Malden, MA, 1995.

[53] Muratbek, D. (2017), Determinants of Non-performing loans in Kazakhstan. WEI International Academic Conference Proceedings (pp. 6-32). Vienna, Austria: The West East Institute, 1995.

[54] Nawawi, A., Salin, A.S.A.P and Nor, N.H.M., Corporate Governance And Investment Efficiency: Malaysian Evidence. 1st International Conference on Religion, Social Sciences and Technological Education (pp. 31-40). Universiti Sains Islam Malaysia, Nilai, Malaysia, 2018.

[55] Nguyễn Thị Hồng Vinh, Nợ xấu của hệ thống ngân hàng thương mại Việt Nam. Bài báo tiến sĩ. Trường Đại học Ngân hàng TP.HCM, 2017.

[56] Norbit, N., Nawawi, A. and Salin, A. S. A. P., Corporate social responsibility practices among the SMEs in Malaysia - A preliminary findings. Management \& Accounting Review, 16(2), 17-39, 2017.

[57] Omar, M., Nawawi, A., and Salin, A. S. A. P., The causes, impact and prevention of employee fraud: A case study of an automotive company. Journal of Financial Crime, 23(4), 1012-1027, 2016.

[58] Ozili, P. K., Non-performing loans and Financial Development: New Evidence. MPRA Paper No. 75964. UK: University of Essex, 2017.

[59] Petersson, J. and Wadman, I., Non-Performing Loans - The markets of Italy and Sweden, Bachelor Thesis, Department of Business Studies - UPPSALA UNIVERSITY, 2004.

[60] Podpiera, J. and Weill, L., Bad Luck or Bad Management? Emerging Banking Market Experience. Czech National Bank, 2007.

[61] Quagliarello, M., Banks' riskiness over the business cycle: a panel analysis on Italian intermediaries. Journal Applied Financial Economics, 119-138, 2007.

[62] Radivojevic, N., and Jovovic, N., Examining Of Determinants Of Non-Performing Loans. Prague Economic Papers, 26(3), 300-316, 2017.

[63] Rahim, S. A. A., Nawawi, A., and Salin, A. S. A. P., Internal control weaknesses in a cooperative body: Malaysian experience. International Journal Management Practice, 10(2), 131-151, 2017.

[64] Salas, V. and Saurina, J., Credit Risk in Two Institutional Regimes: Spanish Commercial and Savings Banks. Journal of Financial Services Research, 22(3), 203-224, 2002.

[65] Salin, A., Malaysian private entities reporting standards - Benefits and challenges to SMEs. International Journal of Academic Research in Business and Social Sciences, 7(11), 1302-1320, 2017.

[66] Salin, A. S. A. P., Manan, S. K. A., Kamaluddin, N., and Nawawi, A., The role of Islamic ethics to prevent corporate fraud. International Journal of Business and Society, 18(S1), 113-128, 2017.

[67] Salin, A. S. A. P., and Abidin, Z. Z., Being transparent: An evidence of a local authority in Malaysia. International Conference on Sociality and Economics Development (p. 10). Singapore: IACSIT Press, 2011.

[68] Sargan, J. D., Estimation of Economic Relationships Using Instrumental Variables. Econometrica, 26, 393-415, 1958. 
[69] Senawi, A. R. and Isa, M. P. B. M., Gold Price As a Determinant of Non Performing Loans : An Analysis of Malaysia. Global Business and Management Research: An International Journal, 6(4), 300-307, 2014.

[70] Shleifer, A., and Vishny, R.W., A survey of corporate governance. Journal of Finance, 737-83, 1997.

[71] Stakic, N., Determinants of the Nonperforming Loans Level Movement in the Banking Sector of Serbia. Bankarstvo, 43(4), 122-145, 2014.

[72] Stern, G. and Feldman, R., Too big to fail: the hazards of bank bailouts, G- Reference, Information and Interdisciplinary Subjects Series. Brookings Institution Press, 2004.

[73] Suhaimi, N. S. A., Nawawi, A., and Salin, A. S. A. P., Determinants and problems of successful ERP implementations - Malaysian experience. International Journal of Advanced Operations Management, 9(3), 207-223, 2017.

[74] Tricker, R. I.,. International Corporate Governance. Singapore: Simon \& Schuster, 1994.

[75] Warue, B. N., The Effects of Bank Specific and Macroeconomic Factors on Nonperforming Loans in Commercial Banks in Kenya: A Comparative Panel Data Analysis. Advances in Management and Applied Economics, SCIENPRESS Ltd, 3(2), 1-7, 2013.

[76]Zribi, N. \& Boujelbène, Y., The factors influencing bank credit risk: The case of Tunisia. Journal of Accounting and Taxation, 3(4), 70-78, 2011.

Received on February $1^{\text {st }}, 2019$

Accepted on March 25 $5^{\text {th }}, 2019$ 